\title{
Empowerment of Micro, Small Medium Enterprises (MSMES) in Coconut Oil Development
}

\author{
Kadek Wulandari Laksmi $\mathrm{P}^{1}$, Ni Wayan Lasmi ${ }^{1}$, Desak Made Sukarnasih ${ }^{1}, \&$ Wayan Sri Maitri ${ }^{1}$ \\ ${ }^{1}$ Universitas Pendidikan Nasional, Denpasar, Bali, Indonesia \\ Correspondence: Kadek Wulandari Laksmi P, Universitas Pendidikan Nasional, Bedugul Street No. 39 Sidakarya, \\ Denpasar City, Bali Province, Indonesia.
}

Received: October 28, 2021

doi:10.5539/ibr.v15n1p52
Accepted: November 30, 2021

Online Published: December 7, 2021

URL: https://doi.org/10.5539/ibr.v15n1p52

\begin{abstract}
Entrepreneurship development at the household level is the forerunner to the growth of an MSME. In the village of Antiga, Manggis District, Karangasem Regency, there is a home-based business engaged in the production of coconut oil (kelentik oil). Currently the level of marketing is only limited to traditional markets while the target is to be able to market products in modern markets. Therefore, this study has the objective to know the level of efficiency of production costs incurred by the producers of coconut oil (kelentik oil) in Antiga village, Manggis district, Karangasem regency; to know how to empower Micro, Small and Medium Enterprises producing coconut oil (kelentik oil) and to analyze the factors that influence the intention of buyers or consumers to buy coconut oil (kelentik oil) in Bali. The research method is a qualitative method. The result is that the production process is still traditional so that production cost efficiency is achieved. Furthermore, the empowerment of MSMEs is not yet optimal as business partners in marketing their products. Several factors influence consumers' intention to buy coconut oil (kelentik oil). So the input that can be given is to improve relationships or networks to be able to expand the market and improve product packaging.
\end{abstract}

Keywords: coconut oil (kelentik oil), MSMEs, productivity, entrepreneurship

\section{Introduction}

Micro, Small and Medium Enterprises are economic activities of the people which are an integral part of the business world with their position, potential, and role to realize a balanced and equitable economic structure in terms of development based on economic democracy. During the economic crisis in Indonesia, MSMEs have persisted, compared to large-scale businesses. And MSMEs are the biggest contributor to the economy. From the following five MSME groups, the coconut oil producers in Antiga Village can be included in the business group that is reserved for small businesses. In order to be able to develop and produce coconut oil to penetrate the modern market, kelentik oil producers can join MSMEs that can protect them.

Entrepreneurial growth in Indonesia is very necessary because it is the forerunner to the establishment of a Micro, Small and Medium Enterprise (MSME). The producers of coconut oil (kelentik oil) is one of the Home Industries that are using the traditional production process. The uses of coconut oil are many, ranging from as an ingredient for cooking to as an ingredient for making soap. The tropics are very suitable for coconut plantations, including in Bali. Coconut fruit in Bali is very easy to get because coconut trees are widely planted in Bali, especially in Jembrana Regency with a total annual production of 16,502.01 tons, Karangasem Regency with 14,539.30 tons of coconut production per year, Tabanan Regency with 11,532 tons of coconut production per year. 69 tons (Bali in figures: 2017). From the results of coconut production, it is very supportive for the coconut oil production process (kelentik oil).

Coconut oil (kelentik oil) is generally processed traditionally. The research was conducted in Antiga Village, Manggis District, Karangasem Regency. The choice of location in this village is because most of the people in that area are producers of coconut oil (kelentik oil), from the information obtained from the community producing coconut oil (kelentik oil) in the village of Antiga, facts are known as follows: 1. the people of Antiga village, Manggis district, Karangasem regency in producing coconut oil (kelentik oil) by still using traditional production process; 2 . The target market of coconut oil (kelentik oil) produced is very narrow, only traditional markets; to penetrate the modern market is very difficult due to buyer behavior factors. There are seven factors of buyer behavior as a consideration when purchasing this cooking oil in the modern market. These factors are based on 
priorities, namely product, individual, promotion, packaging, process, place, and psychological factors (Sundari et $\mathrm{al}, 2018)$. The phenomenon in the field is that the coconut oil producers in this village have not collaborated with MSMEs in Bali.

The development of entrepreneurship is now an important thing to sustain the economy in Indonesia. However, the development of entrepreneurship cannot be separated from the performance of entrepreneurship itself. The theory of the industrial organization perspective (Porter, 1980), states that the company's performance can be determined from the environmental conditions of the company. In achieving the success of MSMEs, an ability is needed to be able to use their resources (Barney, 1991). The ability or competence itself is a characteristic that underlies the emergence of a new business, its growth and survival (Bird, 1995). In this case, there are no coconut oil producers, who are housewives, who dare to move into the modern market and do not know how to market their products in order to make a profit because they do not have the ability to do this. On the other hand, they have not been able to manage their finances well. The formulation of the research problem is as follows: First, how is the efficiency level of production costs incurred by coconut oil producers in Antiga Village, Manggis District, Karangasem Regency? Second, how is the empowerment of MSMEs carried out by coconut oil producers in Antiga Village, Manggis District, Karangasem Regency, in order to achieve the desired market target? And Third, the factors that influence buyers or consumers when buying coconut oil (kelentik oil) in Bali?

\section{Literature Review}

\subsection{Productivity}

Productivity which is meant here is the output resulting from the effective and efficient use of resources, but the quality of the product can compete in the global market. The concept of productivity is explained as the level of efficiency when producing goods and services. Productivity is the level of efficiency when producing goods and services, so this productivity prioritizes how to properly utilize the source when producing goods or services (Sedarmayanti, 2011). Besides that, productivity is a process where the focus is on the output of human resources with a ratio between the output and input (Ramadon \& Pasmawati., 2017). While work productivity is the product of goods or services for each individual or group that provides guidance for consideration between inputs and outputs with more efficient performance actions (Wibowo, 2018). In this case, the producers of coconut oil (kelentik oil) in the village of Antiga, Manggis District, Karangasem Regency use traditional production processes and do not neglect production cost efficiency, to meet market wants and needs.

In order to measure an employee's work productivity, indicators are needed, namely: (Sutrisno, 2016)

\section{Ability}

The ability of employees to be professional when working. Employees are provided with skills to become resourceful when completing their tasks.

2. Improvement of results of achievement

Have the determination to increase the results of achievement. This effort is to increase the company's work productivity and increase the quantity of work results.

\section{Work spirit}

Businesses work better than yesterday and increase work performance. Morale can cause employees to evaluate their previous work.

\section{Self-development}

Self-development is conducted in order to increase work results with existing abilities. By conducting self-development, employees will find challenges as well as hope. The challenges faced by its employees lead to a healthy competition motivation. With the hope that it can have an impact in order to have the desire of employees to increase their abilities.

\section{Quality}

Effort to improve the quality from before. Quality improvement brings benefits in order to increase maximum results for the company and affect better company productivity.

\section{Efficiency}

Comparing its resources with achievements during the work process. Of the five indicators, to measure the work productivity of coconut oil producers in Antiga Village, Manggis District, Karangasem Regency, coconut oil producers have the ability to increase their achievements with high work spirit through developing themselves in improving their quality and always pay attention to efficiency. 
In order to produce quality products, the cost element cannot be ignored. The costs referred to here are all sacrifices incurred in the form of cash, bank money and labor (machines and humans) which are sacrificed to make the required product, namely coconut oil (kelentik oil). Mowen (2012) states that cost is cash or the appropriate value of cash needed to obtain goods or services which bring present or future benefits to the organization. In relation to the financing issued, the efficiency principle cannot be ignored, because efficiency is a good comparison between inputs and outputs, for example, maximum results with minimal use of resources. (Hasibuan, 1984). Efficiency is precisely the way to go about something without wasting time, effort, or money. Efficiency is the ratio between inputs and outputs or expenses with profits (Mulyadi, 2007).

\subsection{Micro, Small and Medium Enterprises (MSMEs)}

In Indonesia, all businesses, from food stalls, street vendors, restaurants, hotels to mining, are categorized as MSMEs. MSMEs are productive economic businesses which stand independently and are carried out by individuals or business entities that can expand employment opportunities and provide broad economic services to the community. In accordance with Law No. 20 of 2008, a just and prosperous society is based on Pancasila and the 1945 Constitution with the realization through national economic development based on economic democracy. In the following law there is a classification of MSMEs which are distinguished by the number of assets and total sales turnover. Meanwhile, based on BPS (the central bureau of statistics) this classification includes the number of employees employed. These classifications are:

1. Micro Business Category / Home Industry

This business is a productive business from an individual or individual business entity with the following criteria:

- Number of workers < 4 people

- Net worth of IDR 50,000,000

- Sales turnover per year up to IDR 300,000,000 .

2. Small Business Category

This business is a productive economic business which is independent and is carried out by individuals or business entities that are not subsidiaries or branches of companies that are owned, controlled, or become part of either directly or indirectly from medium or large businesses according to the criteria of small businesses, namely:

- Number of workers 5-19 people

- Net worth of IDR 50,000,000 to IDR 500,000,000

- Sales turnover per year is IDR 300,000,000 - IDR 2.5 billion

\section{Medium Business Category}

This category is a productive economic business that is established by individuals carried out a person or non-subsidiary business entity or its branch, which controls or as part of it directly or indirectly with a small or large business with total net worth or sales results each year with the following criteria:

- $\quad$ Number of employees 20-99 people

- Net worth is IDR 500,000. 000 - Rp 10 billion

- Annual sales turnover Rp 2.5 m illiar - Rp 50 billion

From the classification and category of MSMEs, the producers of coconut oil (kelentik oil) in Antiga village belong to the category of Micro Business/Household Industry.

\subsection{Empowerment of Micro, Small, and Medium Enterprises (MSMEs.)}

In Law No. 20 of 2008 concerning MSMEs, it is explained that MSMEs are built with the following principles and objectives:

Empowerment principles

1. Fostering independence, togetherness, entrepreneurship of MSMEs in order to have work from their own initiatives.

2. Realizing public policies that are transparent, accountable, and fair.

3. Developing a business based on regional potential and market orientation based on the competence of MSMEs.

4. Increase the competitiveness of MSMEs. 
5. Organizing an integrated plan, implementation, and control.

The objectives of empowerment are as follows:

1. The realization of a national economic structure in which it is balanced, developing, and fair.

2. Emerging and developing the capabilities of MSMEs as strong and independent businesses.

3. Increasing the role of MSMEs in regional development, creating jobs, income distribution, economic growth, and alleviating people from poverty.

While the process of empowerment and achieving the goal of empowerment is done through an approach namely (Suhuarto, 2016)

1. Possibility: creating a climate that allows the community's potential to develop to the maximum. So this empowerment must be able to liberate the community from cultural barriers and hindering structures.

2. Reinforcement: strengthen people's knowledge and abilities when solving problems and meeting their needs. Empowering this community must develop all the capabilities and self-confidence of the community that can produce independence.

3. Protection: to provide community protection, especially to weak groups so that they are not oppressed by strong groups. This empowerment is aimed at eliminating discrimination and domination that does not bring benefits to the underprivileged

4. Support: guiding and supporting so that the community can participate and work. This empowerment provides support for the community so that it is far from getting weaker.

5. Maintenance: maintenance of conducive conditions so that there is a balanced distribution of power between various community groups. This empowerment must provide a guarantee for harmony and balance where possible everyone can get business opportunities.

Empowerment in the process of producing coconut oil (kelentik oil) in the village of Antiga is empowerment by developing the potential of the region as well as market orientation on the competence of MSMEs. Because the village of Antiga, Manggis District, Karangasem Regency is a producer of coconuts that are used as raw material for the manufacture of coconut oil (kelentik oil).

\section{Research Methods}

This research is aimed at housewives producing coconut oil (kelentik oil) and consumers in the modern market in Antiga Village, Manggis District, Karangasem Regency. The research was carried out in this place because the women who produce coconut oil (kelentik oil) are traditional in their production process, and in marketing the coconut oil they produce, the producers still face problems, namely the market is only at the traditional market stage, while the hope is to go to the modern market. Sources of research data are primary and secondary data: primary data sources are direct data from the housewives who produce coconut oil (kelentik oil) in Antiga Village and consumers of cooking oil in a modern market. While secondary data sources are from Bali documents in numbers. The research data are qualitative and quantitative data. Considering that this research is very important for housewives who produce coconut oil (kelentik oil) in the village of Antiga, Manggis District, Karangasem Regency, the production process is carried out traditionally and the target market is only the traditional market, while the hope is that it will reach the modern market. Data collection was done through observation, interviews, and documentation studies. When the data has been obtained it will be analyzed by qualitative methods. The interview instruments used are: 
Table 1. Interview Instruments For Coconut Oil Producer

\begin{tabular}{|l|l|l|l|l|}
\hline Variables & Indicator & Dimension & $\begin{array}{l}\text { Number of } \\
\text { Question }\end{array}$ & Questions \\
\hline $\begin{array}{l}\text { Housewives as the } \\
\text { Producer of Coconut Oil }\end{array}$ & Coconut Oil & Producers & 1 & $\begin{array}{l}\text { Are you a producer of coconut oil: a. Yes., b. } \\
\text { No }\end{array}$ \\
\hline Produce coconut oil & Coconut oil & $\begin{array}{l}\text { Knowledge and } \\
\text { experience }\end{array}$ & 2 & $\begin{array}{l}\text { If the answer is yes, continue to question two. } \\
\text { To produce coconut oil do you use: a. } \\
\text { Firewood, b. Sunlight energy. c. Epj. Gas d. } \\
\text { Kerosene }\end{array}$ \\
\hline Use of fuel & Use of fuel & $\begin{array}{l}\text { Knowledge and } \\
\text { experience }\end{array}$ & 3 & $\begin{array}{l}\text { Why do you use .... (the question leads to the } \\
\text { answer to question number two }\end{array}$ \\
\hline $\begin{array}{l}\text { Using solar energy in } \\
\text { the process of producing } \\
\text { coconut oil }\end{array}$ & $\begin{array}{l}\text { Efficiency of } \\
\text { production } \\
\text { costs }\end{array}$ & $\begin{array}{l}\text { Knowledge and } \\
\text { experience }\end{array}$ & 4 & $\begin{array}{l}\text { Do you understand that using solar energy } \\
\text { have made savings in the process of } \\
\text { producing coconut oil }\end{array}$ \\
\hline
\end{tabular}

Note; This questionnaire can be developed during the interview

Table 2. Interview Instruments For Consumers

\begin{tabular}{|c|c|c|c|c|}
\hline Variable & Indicator & Dimension & $\begin{array}{l}\text { Number of } \\
\text { Questions }\end{array}$ & Questions \\
\hline Coconut oil is sold in the market & $\begin{array}{l}\text { Coconut } \\
\text { oil }\end{array}$ & Understanding & 1 & $\begin{array}{l}\text { Do you know coconut oil (kelentik } \\
\text { oil) is sold in the market: a. Yes, I } \\
\text { know. b. No, I don't }\end{array}$ \\
\hline Consuming/ using coconut oil & $\begin{array}{l}\text { Coconut } \\
\text { oil }\end{array}$ & Perception & 2 & $\begin{array}{l}\text { Are you consuming / using coconut } \\
\text { oil (kelentik oil ): a. Yes. b. Not }\end{array}$ \\
\hline Aware of coconut oil & $\begin{array}{l}\text { Coconut } \\
\text { oil }\end{array}$ & Understanding & 3 & $\begin{array}{l}\text { How do you know about coconut oil } \\
\text { (kelentik oil ): a . from a friend. b. } \\
\text { from the sale }\end{array}$ \\
\hline Packaging of coconut oil & $\begin{array}{l}\text { Packaging } \\
\text { quality }\end{array}$ & Understanding & 4 & $\begin{array}{l}\text { If you know coconut oil (kelentik } \\
\text { oil), how is it packaged: a. Good } \\
\text { quality. b. Poor quality. }\end{array}$ \\
\hline Process of coconut oil. & Process & Understanding & 5 & $\begin{array}{l}\text { Do you understand the process of } \\
\text { coconut oil (kelentik oil): a. Yes, I } \\
\text { understand. b. No, I don't understand }\end{array}$ \\
\hline Buying coconut oil & Buying & Market & 6 & $\begin{array}{l}\text { Where do you buy coconut oil } \\
\text { (kelentik oil) : a. Traditional market } \\
\text { b. Modern market }\end{array}$ \\
\hline $\begin{array}{l}\text { Factors influencing the use of } \\
\text { coconut oil }\end{array}$ & $\begin{array}{l}\text { Aroma, } \\
\text { packaging, } \\
\text { color, } \\
\text { price, } \\
\text { quality, }\end{array}$ & Psychological & 7 & $\begin{array}{l}\text { What factors influence you to use } \\
\text { coconut oil: a. Aroma b. Packaging } \\
\text { c. Color, d. Price, e. Quality f. The } \\
\text { fact that it does not contain chemical } \\
\text { substances }\end{array}$ \\
\hline
\end{tabular}

Note: This questionnaire can be developed during the interview

\section{Discussion}

\subsection{Production Activities}

Based on the results of interviews and direct observations to the research location, data were obtained from 7 informants as coconut oil producers in Antiga Village, Manggis District, Karangasem Regency as follows: The production process to produce coconut oil (kelentik oil) uses fuel from solar energy. Solar energy and firewood are used, as told by the informants, because fuel prices are expensive, such as; prices of gas, and kerosene, therefore in order to save production costs (production cost efficiency) coconut oil producers in the village of Antiga, Manggis District, Karangasem Regency use solar energy and firewood in the production process, (Julianto, 2013). Efficiency is the accuracy of the way (effort, work) in running something without wasting time, effort and cost. Efficiency also means the ratio between inputs and outputs or costs and profits (Mulyadi, 2007). The coconut oil producers in the village of Antiga, Manggis District, Karangasem Regency, in the production process go through several stages, namely: the first stage is grated coconut, the second stage is the grated coconut mixed with enough water, just squeezed, the third stage is exposing it to the sun, it takes 24 hours, the fourth stage separation of coconut oil and waste, the fifth stage of coconut oil which has just been separated from the waste is fried using firewood, the time required for frying is 15 minutes, then afterward the result is coconut oil (kelentik oil). The production process by utilizing solar energy and firewood has been carried out from generation to generation. This 
coconut oil (kelentik oil) is sold in traditional markets, at a price per bottle (600 milliliters) of IDR 15,000 (fifteen thousand rupiah).

\subsection{Empowerment of Micro, Small and Medium Enterprises (MSMEs)}

In the Law of the Republic of Indonesia Number 20 of 2008, as mentioned above, the principle of empowering Micro, Small and Medium Enterprises is to foster independence, togetherness and entrepreneurship, to work on their own initiative. Regional potential-based and market-oriented business development in accordance with the competencies of Micro, Small and Medium Enterprises (MSMEs), with the aim of growing and developing the capabilities of Micro, Small and Medium Enterprises to become strong and independent businesses. Based on the principle of empowerment and the goal of empowering Micro, Small and Medium Enterprises (MSMEs), business development is carried out based on regional potential by the producers of coconut oil (kelentik oil) in the village of Antiga, Manggis District, Karangasem Regency because the village of Antiga, Manggis District, Karangasem Regency is a producer of coconuts,. The raw material for producing coconut oil (kelentik oil) is quite available. The production process is carried out through an independent initiative, namely producing coconut oil by utilizing solar energy and firewood with the aim of growing and developing capabilities to reach the target market. This is in accordance with the objectives of Micro, Small and Medium Enterprises, namely to grow and develop Micro, Small and Medium Enterprises to become strong and independent businesses. In the concept of togetherness, a network is needed in marketing products which is a key to the success of MSMEs. Businesses will be difficult to develop and succeed without good performance and mutually beneficial relationships with other parties (Wilkinson \& Young, 2002).

\subsection{Factors Affecting Buyers/Consumers in Purchasing Coconut Oil (Kelentik Oil) in Bali}

At the time of this research, coconut oil (kelentik oil) was produced by housewives in Antiga Village, Manggis District, Karangasem Regency. But the hope of the producers of coconut oil (kelentik oil ) in the village of Antiga, Manggis District, Karangasem Regency, is to reach the modern market. To be able to provide solutions in this study, researchers collected data through interviews and direct observation with visitors who shopped at one of the modern markets in Karangasem Regency. From information on users or consumers of coconut oil (kelentik oil) in Bali. Of the 9 (nine) informants who shopped at the modern market, one informant stated that he did not know and did not understand coconut oil (kelentik oil), 8 (eight) informants stated that they knew, understood and used coconut oil (kelentik oil) and stated that they always buy it at the traditional market, because in the modern market there is no coconut oil (kelentik oil). The informant's reason for using coconut oil (kelentik oil) is because it has a savory aroma and does not contain chemicals as well as the fact that it comes with standard price. However, the packaging of coconut oil (kelentik oil) is of poor quality because the lid is not sealed, but for a period of 3 (three) months this coconut oil (kelentik oil) has not changed its aroma and color (not to be rancid). The informant stated that he/she did not understand the coconut oil (kelentik oil) production process. Consumers prefer to buy cooking oil with tightly closed packaging in modern markets and those that display the content of the cooking oil and are of higher quality (Sundari, 2018).

\section{Conclusion}

\subsection{Conclusion}

Based on the results obtained, it can be concluded that:

1. The cost of production in the process of making coconut oil (kelentik oil) in the village of Manggis District of Karangasem Antiga can be said to be efficient, because they still use the traditional way of using sunlight and firewood.

2. Coconut oil producers in Antiga Village, Manggis District, Karangasem Regency, carry out their business development based on regional potential that is independent and still needs to collaborate with related MSMEs in order to market their products more broadly.

3. Factors that influence consumers in using coconut oil (kelentik oil) are: the aroma factor is stated to be savory, the fact that it does not contain chemicals, it comes with standard price, and it has clear color.

\section{b. Research Recommendations}

Research recommendations that can be given are as follows:

1. The need to build good cooperation with related MSMEs so that this coconut oil business can be marketed more widely and is better known by consumers.

2. Coconut oil (kelentik oil) to be packaged better in order to maintain quality and to make it last longer. 
3. Other researchers can develop more about how to build a good network to be able to develop a home-based business.

\section{References}

Bali in Numbers, 2013, Bali Publications in Numbers.

Barney, J. B. (1991). Firm resources and sustained competitive advantage. Journal of Management, 17(1), 99-120. https://doi.org/10.1177/014920639101700108

Bird, B. (1995). Toward a theory of entrepreneurial competency. Katz, J. A., \& Corbet, A. C. (ed.), Seminal ideas for the next twenty-five years of advances (advances in entrepreneurship, firm emergence and growth, vol. 21), Emerald Publishing Limited, Bingley, pp. 115-131. https://doi.org/10.1108/S1074-754020190000021011

Hasibuan, S. P. (1984). Basic Management of Understanding and Problems, Mount Agung, Jakarta

https://www.4muda.com

https//accurate.id.bisnis.ukm

Law of the Republic of Indonesia No. 20 of 2008. http//papasemar.com

Mowen \& Hansen, (2012). Cost Management, Jakarta, Salemba Four.

Mulyadi. (2007). System Management Control Planning, Salemba Amazon.com

Sedarmayanti. (2011). Human Resources and Work Productivity, CV. Mandar Maju, Bandung.

Suhuarto, E. (2016). http//papasemar.com

Sutrisno. (2016). Human Resource Management, Earth Literacy, Jakarta.

Tjetjep, R. R. https://opacperpusnas.go.id

Venny, S. et al. (2018). Analysis of Factors Considered by Consumers for Decisions to Purchase Bimoli Cooking Oil at Supermarkets, Wonogiri Regency. https//journal unilak.ac.id

Wibowo. (2018). MSME Business. http://accurate.id

Wilkinson, I., \& Young, L. (2002). On cooperating: firms, relations and networks. Journal of Business Research, 55(2), 123-132. https://doi.org/10.1016/S0148-2963(00)00147-8

\section{Copyrights}

Copyright for this article is retained by the author(s), with first publication rights granted to the journal.

This is an open-access article distributed under the terms and conditions of the Creative Commons Attribution license (http://creativecommons.org/licenses/by/4.0/). 